\title{
Religion Sectarianism in Yoruba Land and Threats to Its Millennial Tribal Union
}

DOI: https://doi.org/10.47175/rissj.v1i2.41

\author{
1,2 University of Ibadan, Nigeria \\ *taimats01@gmail.com
}

| Matthew T. Taiwo ${ }^{1, *} \mid$ Victor O. Taiwo²

\begin{abstract}
The Yoruba people have lived harmoniously as a kin for as long as the tribe has been in existence without religious strain despite the myriads of choices of beliefs that their traditional religion (Iseese) offered; and also, with the advent of foreign religions, Christian and Muslims have continuously live together in Yoruba land, often in harmony with practitioners of Yoruba traditional religion. In the recent age, there has been a curve of trend as the tribal relationships among the Yoruba people have gradually been eroding due to increasing infiltrations and activism of religion extremists. This research examined the damage religious sectarianism wreaked on the kinship relationship among the Yoruba folks. The research was qualitative, and situated within fundamentalism theory, a religious philosophy which depicts advocacy and strict adherence to a religious doctrine or belief. Data collections which are based on both primary and secondary sources are participatory, observatory and library oriented. It is concluded that religion has done more harm than good, but the situation can be redeemed with good understanding of the intended purpose of religion ingrained in the religious zealots. KEYWORDS

Yoruba tribe; religious extremism; iseese; islam; christianity
\end{abstract}

\section{INTRODUCTION}

The Yoruba are collections of diverse people bound together by a common language, history and culture, and are believed, according to Yoruba mythology, to have descended from a progeny called Oduduwa. They spread all over the world, but highly populate Nigeria, Benin, Togo, and the Caribbean. While its existence has been historically traced to $450 \mathrm{BC}$, the Yoruba people constitute one of the largest ethnic groups in the South West of Nigeria. As religion has always run on the same pedestal with human creation, it is therefore conceivable that religion has been with the Yoruba for as long as their existence have been. Thus, the traditional religion known with the Yoruba is known as 'Isese' which translates to original religion. The religious life of the Yoruba is derived from traditions that evolved under the diverse influences of historical and cultural contingency. The Yoruba's religion is characterised by different cultural philosophies and reverences to deities that are regarded as intermediaries between them and Eledumare (the Supreme God). In spite of the polytheist nature of the Yoruba people, kinship was mystical among Yoruba for their status of religious harmony and their understanding of religion as a component of culture. Way back in the fourteenth century, Islam was brought to Yoruba land to be next to the aboriginal religion in Yoruba land in the reigning era of the Mali Empire under the rule of Mansa Kankan Musa (Taiwo, 2019). The history was followed with the emergence of yet another foreign religion in the name of Christianity in the nineteenth century into Oyo Empire, Yoruba land by Wesleyan missionaries (Balogun, 2017). At the evolution period of the new religions, the 
boundaries between the three (Iseese, Islam and Christianity) were not always sharply demarcated as different faiths co-existed. However, with the growing population of the devotees of the two popular foreign religions in Yoruba land, namely, Islam and Christianity, and their indoctrination into the new faiths with strict tenets, the values of the Yoruba traditional religion began to be challenged, thus regarding the traditional religion as paganism and abomination unto God. And, later, with the growing competitions between Christianity and Islam, practitioners of the two religions became perpetual antagonists of each other, but common enemies to Yoruba traditional beliefs (Iseese). Developing from the Muslim and Christian doctrines is the reordering of priorities of relationships which has been shifted from cultural affinities to religious brotherhoods, thus, a trajectory in the tribal relationship that Yoruba people had always enjoyed. In the more recent time, some foreign religion adherents have been extremely demonstrating their obsession for their faiths with high propensity of demeaning importance of tribal relationship for the promotion of religious relationship. This research examined the causes of religion sectarianism in Yoruba land, the damage that has been wreaked on its kinship relationship, and suggested ways the situation can be salvaged.

\section{The Yoruba Traditional Religion}

The religion known with the Yoruba is known as 'Isese' which translates to original practice. Yoruba religion emanated from diverse traditions as no single person could be claimed to have been the founder. The religion, which is the indigenous faith of the Yoruba, was passed down from the genesis of their generation through culture (Omobola, 2014). This stance was substantiated by Janson (2017), that Yoruba religion life is derived from traditions that evolve under the diverse influences of historical and cultural contingency (Janson, 2017).

The Yoruba have deities who stand as intermediaries between them and the same supreme entity known as 'God', who in Yoruba parlance is known as Olodumare or Eledumare. Essentially, the Yoruba claim that their multiple deities only serve as intermediaries through which or whom they commune with God just like Jesus Christ in the case of Christian and Mohammed in the case of Muslim, and that the fact that they have multiple deities does not make them polytheists. Some of the popular deities that have always formed Yoruba religion are: Orunmila, Obatala, Oduduwa, Osun, Ogun, Sango, Oya, Yemoja, Esu, Ajesaluga, Egungun, Ela, Oosa Ife, Osu, Esidale, Ori, Odu, Edan, Sonponno, Orisa oko, Osayin, a few out of more than four hundred deities worshiped by the people. All the above deities, according to the Ifa practitioners, are believed to be emanations of ifa deity connected to the first worshipper known as Orunmila (Taiwo, 2019). Essentially, Orunmila and Ifa are synonymous; Ifa is reputed to be the direct voice of Olodumare (God) and reputed to be a repository of knowledge and hidden secrets of life. It is therefore an instrument of diagnosis of all problems and solutions or medications to the problems. So, as we have several denominations in Christianity and Islam respectively, so the various deities in the Yoruba religious practice could be regarded as denominations of the Iseese religion as well as all emanating from the mother Ifa. The concomitants of the worship of these deities are: invocation by incantation, pouring of libations, sacrificing to the symbol of deities which most often are carved woods which the ardent critics regard as idols (Taiwo, 2019).

\section{Foreign Religions in Yoruba Land}

\section{Islam}

Islam was next to the aboriginal religion in Yoruba land. Way back in the fourteenth century, Islam had been brought to Yoruba land in the reigning era of the Mali Empire under the rule of Mansa Kankan Musa. Although the religion was already here in the land, history made it 
known that it was only practiced by foreigners in Yoruba land as the natives did not embrace it initially. But, with the passage of time and the first mosque ever to be, having been built in the ancient town of Oyo-Ile in 1550, the Yoruba started savouring what the religion stood to offer. Thus, in progression, mosque started sprouting in places like Iwo town (1665), Iseyin town in (1760), Lagos (1774), Osogbo (1889), Ibadan, Abeokuta, Ijebu-Ode, Ilorin, Ede etc. In order to bolster the religion, the Ullamahs (Islamic teachers) started establishing Quran teaching centers known as Madrasts all over the places. And so in leaps and bounds, the entire land was saturated with the Islamic faiths. Islam was brought to Yoruba land by the Malians in the fourteenth century. This was why the old generation of our people regarded Islam as the religion of the Mali (Esin awon Mali) which flawed on to be 'Esin Imale' (the religion of force) (Taiwo, 2019).

Notwithstanding, the Muslims who eventually accepted Western education also embraced it with the Western culture. Thus, a typical Yoruba Western educated Muslim had multiple identities of being a traditional, Islamic and Western personality (Muhib, 2011). In essence, an educated Yoruba Muslim was bound to have the entire virtues contingent to form his personality.

\section{Christianity}

Although the first attempt by the Europeans to bring Christianity to Yoruba land was in the fifteenth century, precisely between the 1470s and 1620s through the hands of Augustine and Capuchin monks of Portugal, history however has it that their efforts did not succeed due to some unstipulated factors. However, with the efforts of the Methodists and Baptists in the 1840s, a degree of success was recorded. But the visible success started its evolutions via the establishment of the first mission by Henry Townsend of the Church of England in Badagry and in steady progression, the first church namely, The Cathedral Church of St. Peter Wilhelm. Now as a matter of tributes, the heroes of the advent of Christianity in Yoruba land were the Augustine and Capuchin monks of the Catholic Church, Thomas Birch Freeman, Henry Townsend and a native of Yoruba, Andre Desalu Wilhem (Taiwo, 2019). When the missionaries came, they deployed the ingenuity in their approach of winning the hearts of the natives by bringing about civilisation, enlightenment and progress to the Yoruba land (Rotimi, 2015). The missionaries introduced schools for the education of the children, they established health system to take care of the health needs of the people, and lives of people in the generality were highly improved. All these programmes reinforced by the establishment of churches here and there made Christianity more acceptable than Islam and pushed the traditional settings to the background (Taiwo, 2019). Today, we have more churches of different denominations sprouting at every street of Yoruba towns and cities in Yoruba land.

\section{Inter-Religious Contests}

The Jews had traditional religion known as Judaism which is cohesive with Jewish culture. It is summarily impossible to separate the Jewish religion from their ways of life as theology, law and innumerable cultural traditions are all entrenched in Judaism. Regardless of the dynamics in Judaism which bore down to emergence of Orthodox, Conservative and Reformist denominations, the foundation of Judaism in the generic was anchored by Abraham (the father of faith). In essence, Abraham handed down to the Jews, the religion with cultural values.

The Jews give privileged status to their religion (Judaism) over any other religions and they reject each of any foreign religions in turns (G. Sapir and D. Statman, 2015). It is even astounding that Christianity which came as a new covenant religion purported to replace 
Judaism is equally not embraced. The statistics of the population of religious devotees among the Jews shows that Judaists constitute about $81 \%$, and Christian $2 \%$ of all other religions (Pew Research Center, 2016). Judaism has perpetually been portrayed as the religion cum essential component of the Jewish nationality. The Jews do not separate ethnic identity from common religious tradition; religion are harmonised with ethnic factors (Rubinsten, 1967). Thus, the Jewish nation and Judaism have always been treated as being synonymous. Nobody could have thought that it was possible for a Jew to separate religion from the Jewish nationality, for such venture would automatically means separating oneself from Jewish community. It was not until the nineteenth-century, that the western-oriented Jewish intelligentsia began to challenge the fusion of the State and nationality (p.108). But then, the secularists could not withstand resisting forces from the religious Jews who described such debates as aberration, profanity and un-Jews. Nevertheless, the scenario of marriage between tribalism and religion which typify the Jewish identity is not exclusive to the Jews, but also existing in some other cultures.

It is noteworthy that, Islam religion was not primordial with the Arabians. The pre-Islamic period in Arabia was characterised by polytheism (the belief and religious references to many gods or deities). Regular worships of natural phenomena such as stones, tree, sacrifices of animals, visiting of sacred places and consultation with Soothsayers defined the preIslamic Arabian period. Shutao (2016) in "The Origin of Islam in the Arabian Context" puts it that, "tribalism or tribal humanism represented a more deep-seated system of belief in preIslamic Arabian peninsula" (p.12). Before the advent of Islam, Arabs were generally committed to, and defending their tribe. Polytheism was a practical and flexible practice among the Arabians; their value system focused on the tribe rather than over individuals. Unlike Islam which, enforced conformity to their strict tenets, pre- Islamic Arabians religious belief did not enforce any emotional commitment or loyalty on people (Shutao (2016). The advent of Islam altered Arabian pre-Islam religious norms, and replaced with Muslim tradition, a resultant effect of the Muslim constant attacks on tribalism for ignorance of religion and tribal loyalty at the detriment of individual's religious belief.

At this junction, we need to invoke the essence of monotheism and polytheism. Monotheism depicts the religions belief in, and worship of one God, while polytheism connotes the belief in, and worship of multiple gods. When the European adventurers or colonialists as well as the Islamic missionaries came to this part of the world, their criticism of the Yoruba religion is in their polytheism which they eventually regarded as paganism. But what does paganism connote?

Paganism is a disapproving and derogatory description of a religion not reckoned with as one of the world's major or acceptable religions. Therefore, if they could find their ways, the Yoruba religions should be obliterated from reckoning. The hottest critics of the traditional religionists were the European colonialists at their advent in Yoruba land. They did not confess that they had come for colonization alone but asserted their mission to evangelise with their missionary commission. So, it was no wonder the Europeans were all out to vilify and demonise the traditional religious practices and so went with all velocity to convert the natives to the new Christian faith. As a matter of fact, they went as far as commissioning some of the African clerics among the missionaries to research into the native religious practices with the aim of demonizing the practices.

One of such commissioned clerics was one Bishop Emmanuel Moses Lijadu, a Yoruba catechist and evangelist, who, in the service of the European masters wrote a book in 1908 claiming the knowledge of Ifa and coming out to counter each verse of the Ifa with a Bible verse, thus justaposed against it rendering the Ifa verses demonic. But as things turned out, the book written by the Bishop E.M. Lijadu did not achieve the desired result. And so, he 
pledged to his masters that he would personally feign initiation into the Ifa cult to be able to know the nitty-gritty of it rather than the surface study and assessment of the secrets of the religion. Thus, Bishop Lijadu enrolled properly for the initiation and launched himself into the depth of the learning. This time at the mastering of the knowledge of the religion and ascertaining the true and potent efficacy of Ifa as a thing of pride and utter usefulness for human development rather than the intended truth manipulation and deliberate demonization and condemnation by his European masters. Lijadu literally offered to be realistic and honest, and so opted not to be a quisling destroying the legacy of his own people to the satisfaction of his masters. And so he chose to write the truth he discovered in his learning of the efficacy and potency of the religion. Thus, he became the hero of the Ifa deity rather than go back to his masters. In spite of this, the castigation of and aspersions on the traditional religions continued unabated by the Europeans. Such was the absolute contempt and derogation at which the Yoruba traditional systems were held by the Europeans.

Now, aside from the Europeans cynics who see nothing good in the system, the worse assailants of the traditional systems are the converts and contemporary Christian and Islamic clerics and religious zealots. The Christians are quick to quote the Bible verses of Exodus 20:3-4:

Thou shall have no other gods before me, thou shall not make unto thee any graven image, or any likeness of anything that is in heaven above, or that is in the earth beneath, or that is in the water under the earth.)

So, it is delightful to castigate traditionalists as idol worshippers (Aborisa and Elebo). As a matter of fact, the name Babalawo which is only equivalent to the title of a Priest, Pastor or Alfa is to them an anathema. And funny enough, they go to the extreme of demonizing their traditional skills in healing with herbs and roots. What this brand of Christians are portraying here is that outside prayer invocations, God has instructed them against the use of herbs so as not to be likened to the herbalists and Babalawo who trade in leaves and herbs.

According to Justice Jire Arasi (Rtd) in his autobiography titled "Stars to Judicial Excellence" , "Over the years, Ifa has been regarded and painted as pagan and fettish. Many have given Ifa a religious look. It is meant only for the heathen people. This is not true!" (Arasi, 2008).

Another grey area is the perpetual antagonism of Christian by the Muslim. Sometime in the year 1992, a religious crisis erupted at the University of Ibadan between Christian and Muslims over citing of Church and mosque. Of late, also the crisis of hijab wearing by females in the school was instigated in Lagos and Osun States respectively. Some zealots were reported to be not only propagating but enforcing the wearing of hijab at the International School, Ibadan which is under the private ownership of the authorities of the authorities of the University of Ibadan. Also was an instance of a secondary school vice principal of a public secondary school which was a Christian school by foundation, the woman was turned down by the principal from being a teaching staff in the school on the basis of her being a Muslim -wearing of hijab.

Sometime in the month of July, 2018, a release from a "Press Conference on the state of the nation" was made which was titled, "Yoruba Christian Leaders, stop parading yourselves as Yoruba Elders" by Muslim Community of Oyo State where they described a purely 'Yoruba Interest Organisation'. The organisation which was at the time chaired by a Muslim devotee was claimed to be a Christian organisation on the basis that the Christians in the organisation outnumbered the Muslim. A quote from the press statement read:

It is however crystals clear that this amalgam of Christian predators' modus operandi in its absolutism is furthermore of Christian political domination in the 
southwest and ostracisation of the Muslims who constitute the majority in four out of the six states in the region. What an absurdity!!.)

Foreseeing religious catastrophe being ignited in Yoruba land, Victor convened a peace summit conference tagged "Yoruba Interreligious Harmony Projects" aimed at promoting peace in Yoruba land among the adherents of the three popular religions in Yoruba land namely, Christianity, Islam and Traditional (Iseese).

In the meeting, where the three religions were specially represented by religion figures in the person of Rev. J.K Idowu (Christian), Dr. Wole Abass (Muslim) and Surveyor Adefabi Fadiran (Iseese), the reality of ethnic disregard at the instance of religion sentiment was clear. Dr. Wole Abass confirmed the support of other Muslim bodies for the press statement of the Muslim community of Oyo State while he stressed that "the Muslim have been cheated in all fronts by the Christains. Emphatically speaking, he confessed that there is a religious war already in Yoruba land but only that it is not yet blown out due to the tolerance of the Muslims. One Alhaji Waheed Hassan was well disposed to understanding unity based on religious affiliation even with non-Yoruba tribe in as much they are of the same religion, but not from the perspective of ethnic affinity or kinship.

A Christian Association of Nigeria (CAN) Oyo State chairman attended the summit with his demeanour expressing dissatisfaction of being congregating with unbelievers, who the Muslims and Traditional religionists symbolized according to his own religion, but was forced to come under the command of a highly revered principal. Thus, he did not make a single remark to show his pleasure or support for the religious harmony summit, as he also left after a brief stay leaving others behind.

A Muslim organisation popularly known as Muslim Right Commission (MURIC), claiming its responsibility of fighting for Muslim rights has been very controversial on media for his unrepentant castigation of Yoruba interest inclined projects. In as much as such project is not initiated and managed by the Muslims, the organisation claims, it is religious sentimental, aimed at denigrating Muslim dignities, violates the Muslims' right, aimed at ostracizing the Muslims, and/or not in the best interest of the Muslims.

A political debate known as National Conference of the Federal republic of Nigeria was to be held in year 2014 where all geopolitical zones in Nigeria would have delegations. It is a normal practice for each geopolitical zone to organise in-group conference to discuss their interests and make resolutions to be presented at the national conference. There was an advertorial in a Nigeria Daily Newspaper edition of Tuesday 25 February, 2014 where invitation to all Yoruba Patriots was advertised without any qualification requirement other than being a Yoruba from the South West, to the 'Yoruba Constitutional Conference'. The purely political debate was later found to have been given dimensions by a Muslim organisation called (MUSWEN), Muslim Ummah of South West Nigeria.

In their release in response to the conference, the MUSWEN raised objection to the conference where they participated without restriction that "the meeting was a deliberation among certain personalities of Yoruba extractions that were mainly non-Muslim". They were of the opinion that while the personalities included well-known Christian clerics who would have guided the deliberations along the lines of the Christian faith, they did not include Muslims equally versed in the Islamic faith to ensure a religious balance in decisionmaking. The MUSWEN declared that many of the statements and declarations contained in the document which is the resolution from the conference were indeed breach of the faith of Muslims and therefore the purported "Yoruba Agenda" is, to the extent of such breaches, totally unacceptable to Yoruba Muslims of the South-west. The MUSWEN by their argument apparently tend towards pledging their loyalty to Muslim communities irrespective of the tribe than to their ethnic communities. 
The Christian represented in the body called Christian Association of Nigeria (CAN) are not also justified in tolerance for non-Christian religion, most especially the Muslim. The CAN's apathy for Islam is palpable for serial allegations of agenda of Islamisation of Nigeria and the habits of condemning any non-Christian faith (with indirect references to Islam) to eternal damnation. Many practicing Christians are loath to find an atmosphere friendly to encourage ethnic interest and relationships.

Notwithstanding the discrepancies in the principles of the imported European and Arabic religions into the Yoruba land, much tolerance is embraced among the adherents of all religions among the people. Except for extremism that began to grow as times passed by, most religious practices among Christian and Muslim operate on the surface of faith. While they profess their own foreign beliefs, involvement in other religions either directly or indirectly is still much a reality. Consultations across religions at the instance of perceived spiritual problems are not abomination among the religionists. While it may be sometimes difficult to quickly identify a Muslim man in the non-Muslim gatherings, women folks in hijab congregating with Christians on prayer mountains, special prayer meetings in churches and several kinds of Christian gatherings are not oblivious. As a personal witness, a good number of seers in a white-garment spiritual church are either hijab wearing practicing Muslims or Muslim names bearers. Some secretly come while others come by commission even without renouncing their Islamic faith. This attitude is one that actually is against Islamic tenet of monotheism, and yet they see nothing wrong in congregating where they believe they can find solace.

For the strong doctrines in Christianity which condemn any form of Christian involvement in anything different from Jesus, some of the adherents, though not likely to be found in Muslim congregations, do secretly consult the Muslim clerics (Alfas) or Traditional priests (Babalawo) for divination. Incidentally, they may not be religiously disposed to people of other religions, but they inwardly believe that anyone can be gifted with mystical prowess irrespective of the religion he practices. Their professed religions in such situations are mere religious expression but the reality of life lies in their personal conviction and belief.

\section{Social Relationship}

At the level of cultural bond and social relationships, all religions among the Yoruba people are contingent. Every family in the Yoruba land is, either consciously or not, connected with Iseese (the ancestral religion). The Yoruba people are culturally polytheists for their beliefs in deities that numbers more than 400, each represented with different objects of natural phenomena. Despite the foreign religions that permeated to wipe off the Iseese consciousness, the cultural and tribal bonds among the families could not in any way be severed. In every family in Yoruba land, people of different religions, the Christians and Muslims are mixed relatives. Celebration of religious festivities with relatives and crossreligious marriages form social contraptions that defy solutions, and also, are clerics who swap one religion for another. There are cases of people who practice two or three religions concurrently; not because they are polytheist but because they see God as the central subject of worship regardless of the religion nomenclature. What makes the difference to such people is their philosophy to religions- that God is one, though the means and modes of reference may be different. An example is Dr. Peter Fatomilola (a lecturer in Obafemi Awolowo University, Nigeria). He is an Ifa practitioner (an ifa descendant), knowledgeable in Quran and prays in Arabic and a practicing Christian (claiming being born again). He had said in an interview with (TNV) The Nigerian Voice in 27 Sep. 2006 that, Ifa is the origin of his belief (Iseese) and thus cannot throw it away for foreign religions. Cross religion 
practices blend with his concept of religion and beliefs. It can thus be concluded, that religious conflicts have mostly been responsible for by gullible zealots who are lacking in understanding the fundamentals of religion in its relation to human life.

\section{ANALYSIS OF FINDINGS}

Iseese is the Yoruba traditional religion that is still as relevant as any other world religions. But, the tragedy of many generations in Yoruba land is the neglect of their culture and the way of the elders who were the repository of invaluable experiences and wisdom from which coming generation can tap into during trying times. Among the flaws detectable in the Yoruba religion was that it was not systemized and so has no written records, the religion was preserved in its crude form. There are no trained minds to raise the religion to higher consciousness. Since the religion has no written records by which the past can be gleaned and evaluated with the present towards redefining and improvement, the innovation found in imported religions with their system used records are not found in the traditional religion (Omoleye, 2012).

When the European adventurers or colonialists as well as the Islamic missionaries came to Yoruba land, their criticism of the Yoruba religion is in their polytheism which they eventually regarded as paganism. When the Christian missionaries came, they deployed such ingenuity in their approach of winning the hearts of the natives by introducing schools, health system, infrastructure and developmental facilities and civilisation to improve the way of life of the locals. All these programmes made Christianity acceptable and pushed the traditional settings to the background. Ditto the Muslim who were westernised along Arabic knowledge denounced the traditional religion which was considered secretive and thus regarded as pagan and fetish.

Religious dogmas, which the zealots hardheartedly absorb without questioning, and deviations in the interpretations of the doctrines also form strong element of inter-religious disharmony among the Yoruba. The gullible believers have been reconfigured from holding their faith with moderate wave to becoming extremists who reject any faith different from their own. Sectarianism attitude has not only been religion confined, the consciousness has also been extended to tribal and cultural environments. The extremists have reordered the importance of relationships by undermining the culture for the uplift of religions, and showing preference for religious brotherhood at the detriment of kinship.

\section{CONCLUSION}

Religions are meant to serve the purpose of elevating human consciousness and promote their spiritual well being. However, instead of religions to be the means of worshipping God, and an instrument of service to humanity, it has paradoxically turned to an instrument of hatred and war among mankind. Religion has been found to have done more evil than good especially on the aspect of social, cultural and tribal relationship by its constant fuelling of disharmony by religious extremists on the basis of their strict and uncensored religious principles. For religions to fulfill its essence, it is imperative for religious practitioners to learn to coordinate both the spiritual and cultural consciousness of people, concentrate on the positive aspects of their religions and cultivate the attitude of tolerance. Adherents of a religion should be conscious that religion is personal, and as they have a right to their own belief, so must everyone be accorded the same right without undue infiltration. Religion should be understood as a phenomenon of personal conviction in reference to their beliefs, and conscious spiritual communication between a believer and his center or object of worship. 


\section{REFERENCES}

Balogun, Y. (2017). The emergence and contribution of Christian missions to the civilisation of Yoruba Kingdom in the Old Oyo Empire

Janson, Marloes. (2017). Portrait: J.D.Y. Peel. Studying Religious Pluralism in Yorubaland: A tribute to J.D.Y Peel. Religion and Society

Lambe Arasi. (2008). Stars to Judicial Excellence

Mike Omoleye. (2012). Yoruba Traditional religion in the Light of the Qabalah

Muhib, Opeloye. (2011). The Yoruba Muslim' Cultural Identity Question

Odejobi, Omobola. (2014). Influence of Yoruba Culture in Christian Religious Worship

Olanrewaju, Joseph. (2009). The Relationship between People and Supernatural Beings in Yoruba Traditional Culture

Omotoye, Rotimi. (2015). Christianity as a catalyst for Social, Economic and Political change in Yoruba, Nigeria: An Account of a Church Historian

Pew Research Center (2016).

Rubinsten, A. (1967). State and Religion in Israel

Sanni, Kunle. (2014). The position of Muswen, Muslim Ummah of South west Nigeria. Our Objections to the Yoruba for the 2014 National Conference: Our Objections

Sapir, Gideon. and Statman. (2015). Daniel; Minority Religions in Israel

Shutao, Wang. (2016). The Origin of Islam in the Arabian Context.

Taiwo, Tope. (2018). Being the Minutes of the Maiden Meeting of Yoruba Interreligious Harmony Project which took place at the NUJ Hall of BCOS, Orita Basorun, Ibadan.

Taiwo, Victor. (2019). A Treatise for Peace in a Multi-Religious State.

, (2018) My Rejoinder: Towards the Sustenance of the Sanctity of Yoruba

Race Against Religious Extremism: Being a rejoinder to the Press Conference addressed by Alh. Ishiaq Kunle Sanni on 26th June, 2018 in his capacity as the Chairman Muslim Community of Oyo State.

Voice. (2006). The Nigerian; I'm Deeply Spiritual 